\title{
MILITARY EXPENDITURE IN TURKEY: A COINTEGRATION ANALYSIS
}

\author{
Emre ÖZYERDEN ${ }^{1} \quad$ Cevat TOSUN ${ }^{2}$
}

\begin{abstract}
Military expenditures can be affected by countries' present and potential threats as well as several other economic factors. This situation requires analysis of the reasons for changes in military expenditures in the country. In this study, militaryexpenditures of Turkey between 1970-2017 period are analyzed within the scope of its allies, external threats and internal threats as well as other explanatory variables. For external threat data Greece's militaryexpenditure, for allies data North Atlantic Treaty Organization countries'militaryexpenditures, for internal threat data terror incidents index and Turkey's per capita gross domestic product are used as an explanatory variable. Cointegration test was performed using ARDL method with the data collected from various internationally accessible and open sources. Greece's militaryexpenditures and terror index have been found in a positive long term relationship with Turkey's militaryexpenditures.
\end{abstract}

Keywords: Military expenditure, terror incidents, ARDL cointegration analysis

JEL Code: H56, C22, N40.

\section{Introduction}

The allocation of adequate resources to militaryexpenditures is a feature that always conserves priority and importance in every state's budget. This is because militaryspending is used not only in the formation of states but also in the borders of the country and against external threats. In public economy literature, national militaryexpenditures have the characteristics of pure public goods (Rosen \& Gayer, 2008: 52). If it is produced, the fact that the benefit is not divisible personally and that no one can be deprived of the use of the service transforms militaryexpenditures into a social qualified commodity. Military expenses in this axis have an increasing trend for different countries in some periods but they are an indispensable expenditure item.Due to its geographical location, Turkey has been no exception to this generalization. Turkey is located between Europe and the Middle East which is described as an unstable region.In this state, Turkey has the potential to be affected by external threats and internal dynamics that have both have the potential to trigger militaryspending.

This study analysis Turkey militaryexpenditures for 1970-2017 period with ARDL cointegration method.In the literature, besides the threat of the neighboring country, which is frequently applied in the country examples, the analysis of the North Atlantic Treaty Organization's (NATO) militaryexpenditures and the index of terrorist incidents were analyzed.

\footnotetext{
1 Res. Asst., Hitit University, emreozyreden@hitit.edu.tr (corresponding author)

2 Asst. Prof. Dr., Hitit University, cevattosun@hitit.edu.tr
} 


\section{The Scope of Military Expenditures}

At the level of the North Atlantic Treaty Organization (NATO), the International Monetary Fund (IMF) and the United Nations (UN), different definitions of militaryspending are made.The fact that these definitions are different from each other cause this concept not to be accepted by everyone. Brzoska (1995: 46-49) points out the content of the definitions and the areas where expenditure details are partially or completely hidden / kept due to militaryexpenditures due to the strategic goal and structure adopted by the countries. The definition of the Stockholm International Peace Research Institute (SIPRI), which includes all current expenditures and capital expenditures, is frequently used in the literature.According to this definition, militaryspending includes military forces, including peacekeeping forces, militaryministries and other state institutions in militaryprojects, spending on education and equipment of paramilitary forces and military space activities (SIPRI,1973).

What service elements should be included in the scope of militaryexpenditures is shaped by internal and foreign policy elements beyond the definition of this concept.These elements complement each other and take into account the foreign policy which may be a threat to the security of the country and they are shaped according to the economic policy for the country (Sümer, 2005: 84).Dehong (2009: 82) argues that the purpose of the military is to defend, that militaryis an objective of foreign policy for almost all countries, and that militaryspending has a burden on the economy, and expresses this relationship as synergy between economy and military.

The military potential and military power of the countries are analyzed in the literature on the military capacity of a state or the ability to maintain a war. (Biddle, 2004: 2). Barnett (1992) points to the basic inputs of militaryand military spending, stating that military power is related not only to people but also to the ability to mobilize material resources for external security. From a macro perspective, military capacity is expressed as the gross numerical values of the material resources of the state and the military units of the countries play a role not only in the threat of war but also in the "arms race, alliance formation, conflict process and deterrence" (Biddle, 2004: 2-4).In this context, the reduction of militaryspending means that the national military potential will decrease. As such, militaryspending in each state budget is as important as education and health expenditures (Saunders, 1993: 26).

The following table shows the shares of the militaryexpenditures of the Organisation for Economic Co-operation and Development (OECD) countries and Brazil, Russian Federation, Indonesia, India, China, South Africa(BRIICS countries) in gross domestic product (GDP). 
Figure 1. Military Expenditures according to Shares in GDP at OECD and BRIICS Countries

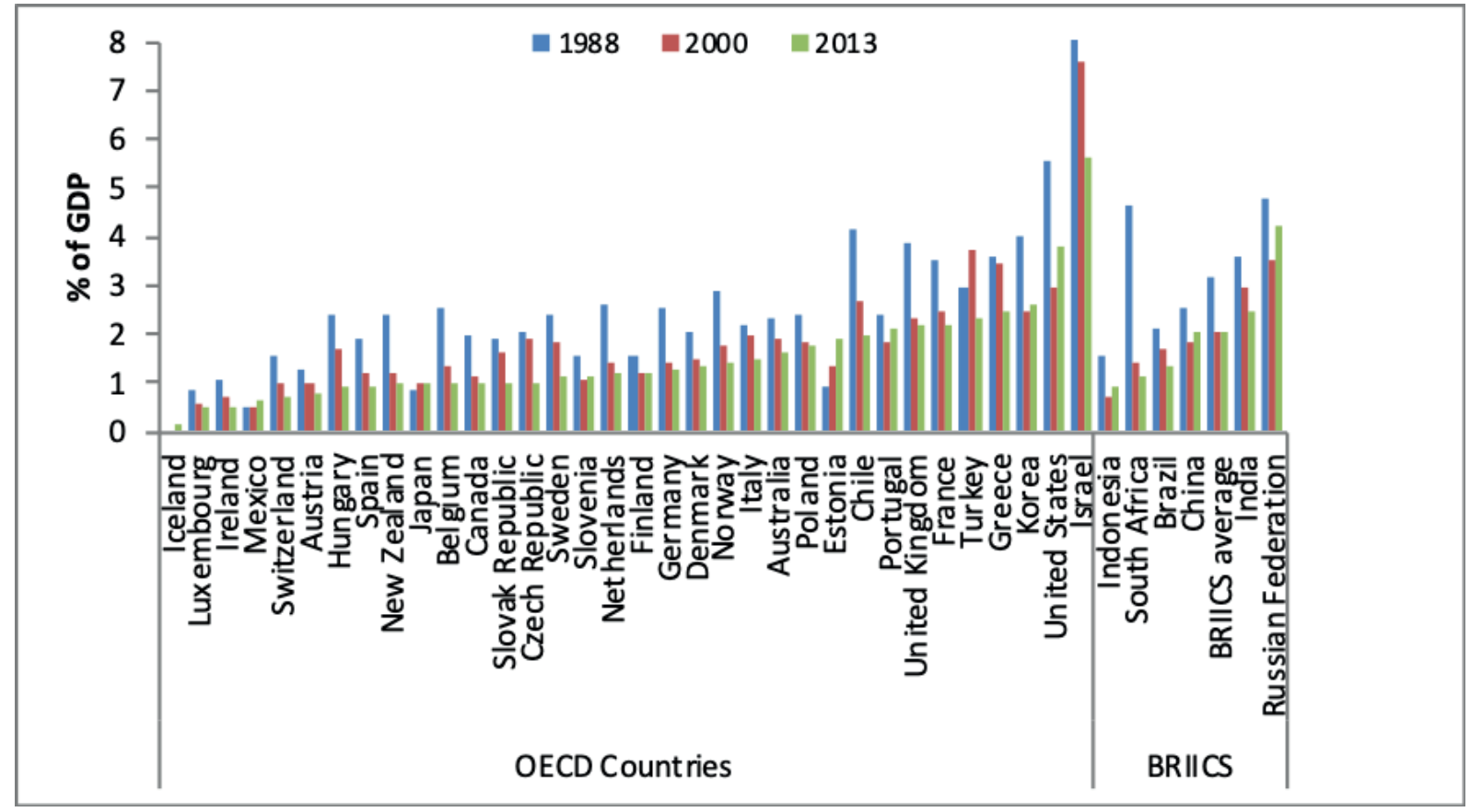

Source: OECD, 2016:48

Although the financial constraints are the main reasons of the change in the public expenditure distribution from the 1980s to the 2000s (Looney, 1994: 17), there is an increase in one-fourth of the 40 countries in contrast to the general decline trend. This trend has an important role in the perception of threat as well as internal and external dynamics. This situation necessitates the analysis of the change in militaryexpenditures. In the following section, the literature on the dynamics behind this change is given.

\section{Literature on the Change in Military Expenditures}

In the literature, there are empirical studies for country groups in addition to country-based studies to explain the change in militaryspending. The first empirical studies were based on Richarson's (1960) model of armament racing, which included countries that were potentially susceptible to active conflict (Smith, 1989).The studies carried out in the following years are composed of studies that include a relatively more comprehensive empirical tests that focuses on economic and political factors as well as military expenditures. Hartley and Sandler (1990) describe variables that are the key determinants of militaryspending, including gross domestic product, threats, the situation with allies, strategic changes and government priorities. This relationship is frequently found in empirical tests in the literature, and studies on the axis of country examples will be included below.

Looney and Mehay (1990) tested the militaryexpenditures of the United States of America (19651985) for the period of 1965-1985, using the predicted and unforeseen Soviet militaryexpenditures, inflation, federal incomes, federal deficits, NATO spending and dummy variables for Vietnam. As a result, the coefficient of the delayed value of militaryexpenditures was found to be close to 1 . 
Smith (1990) analyzed the changes in the UK's militaryspending for the period 1949-1987 and tested the US militaryspending and the Soviet militaryexpenditures and the Korean War as a dummy variable.

Schmidt, Pilandon and Aben (1990) addressed the criteria for militaryspending based on France and the differences in the definition of SIPRI. Then, they analyzed French militaryexpenditures for the period of 1965-1978 in the frame of SIPRI's definition.In the study using GDP as the income variable, they analyzed NATO spending as well as spending on Allied Africa and Soviet spending.

Fritz-Abmus and Zimmermann (1990) analyzed German militaryspending for the period 19611965. In the study which uses the GDP, French militaryexpenditures and NATO militaryexpenditures as an independent variable, the composition of the expenditures made by the government is used as a dummy variable.

Murdoch and Sandler (1990) examined Swedish military spending for the period 1958-1985. Population, GDP, Norway's militaryexpenditures, and Soviet militaryexpenditures were used as independent variables.

Deger and Sen (1990) examined the militaryspending of Pakistan and India. In the analysis, in addition to the GDP variable, they used arms exports, weapons production and the proportion of public expenditures.

Kollias and Paleologou (2003) analyzed Grecee and they found significant impact with income, political factor and strategic variables.

Sezgin and Yildirim (2002) investigated Turkey's militaryspending between 1951-1998 period. According to the results of this study with some safety factors, Greece and NATO's militaryspending has been found to affect Turkey's militaryspending. In the case of country-specific studies, it is seen that the threat perception from neighboring countries and the expenditures arising from allies are evaluated together. In a wider perspective, it is seen that NATO spending is used as an independent variable in explaining militaryexpenditures. In the following section, militaryexpenditure for Turkey will be analyzed. In this context, militaryexpenditure data were collected from SIPRI, the terror index ${ }^{3}$ was derived from the Global Terorism Database (GTD), while the GDP and population were compiled from the World Bank's database.

\section{Methodology and Estimation}

In this study, military spending of Turkeybetween 1970-2017 (Intrmilpc), is analyzed within the scope of external threats, internal threats, allies'military spending and other explanatory variables.For external threat data Greece's military spending (Ingrmilpc), for the Allies data NATO's military spending (Innatomilpc), for internal threat data domestic terror index (ter) and Turkey's people the gross domestic product (Ingdppc) were used asexplanatory variables. Military expenditures and gross domestic product were usedin natural logarithmic termsand per capita values, while the terror index, which contains 0 values, was formed by the inverse hyperbolic sinus transformation which is close to the logarithmic scale.

The following table shows the Augmented Dickey-Fuller (ADF) and Phillips-Perron (PP) unit root

${ }^{3}$ The index of terror was formed by the index $=$ number of events $+($ number of deaths $* 3)+($ number of injured

* 0.5 ) instead of the GTD index. 
test results of the variables.Accordingly, while some of the data are stationary at the level $(I(0))$, some become stationary when the first differences are taken (I (1)). Therefore, ARDL bounds test method, which allows analysis with both I (0) and I (1) data, is adopted.

Table 1. Unit Root Tests Results

\begin{tabular}{|c|c|c|c|c|c|c|c|c|}
\hline \multirow{4}{*}{ Variable } & \multicolumn{8}{|c|}{ Unit Root Tests for Variables } \\
\hline & \multicolumn{4}{|c|}{ ADF } & \multicolumn{4}{|c|}{ PP } \\
\hline & \multicolumn{2}{|c|}{ Level } & \multicolumn{2}{|c|}{ 1st Difference } & \multicolumn{2}{|c|}{ Level } & \multicolumn{2}{|c|}{ 1st Difference } \\
\hline & Constant & $\begin{array}{l}\text { Trend and } \\
\text { Constant }\end{array}$ & Constant & $\begin{array}{c}\text { Trend and } \\
\text { Constant }\end{array}$ & Constant & $\begin{array}{c}\text { Trend and } \\
\text { Constant }\end{array}$ & Constant & $\begin{array}{c}\text { Trend and } \\
\text { Constant }\end{array}$ \\
\hline Intrmilpc & $-3.30 * *$ & $-3.30 * * *$ & $-5.09 * * *$ & $-5.20 * * *$ & $-2.96 * *$ & -2.78 & $-5.30 * * *$ & $-5.28 * * *$ \\
\hline Ingrmilpc & $-2.86^{*}$ & -3.02 & $-4.57 * * *$ & $-4.71 * * *$ & -2.51 & -2.50 & $-4.57 * * *$ & $-4.74 * * *$ \\
\hline Innatomilpc & -1.80 & $-5.95 * * *$ & $-4.23 * * *$ & $-4.19 * * *$ & -1.84 & -1.98 & $-4.25 * * *$ & $-4.21 * * *$ \\
\hline ter & $-5.05 * * *$ & $-6.14 * * *$ & $-9.43 * * *$ & $-9.33 * * *$ & $-5.15 * * *$ & $-6.15 * * *$ & $-10.30 * * *$ & $-10.72 * * *$ \\
\hline Ingdppc & 0.20 & -2.40 & $-6.55 * * *$ & $-6.51 * * *$ & 0.22 & -2.55 & $-6.55 * * *$ & $-6.50 * * *$ \\
\hline
\end{tabular}

Note: Significant at $*=\% 10, * *=\% 5, * * *=\% 1$ level

In this study, the ARDL prediction module of the Eviews 10 econometric software was used and the selection was made according to the following model with a maximum of 6 lags constraints:

$$
\begin{aligned}
\text { lntrmilpc } & =\beta_{0}+\sum_{i=1}^{n} \beta_{i} \text { lntrmilp }_{t-i}+\sum_{i=0}^{n} \beta_{i} \text { lngmilp }_{t-i}+\sum_{i=0}^{n} \beta_{i} \text { lnnatomilp }_{t-i} \\
& +\sum_{i=0}^{n} \beta_{i} \text { ter }_{t-i}+\sum_{i=0}^{n} \beta_{i} \operatorname{lng}_{\text {ln }} p_{t-i}
\end{aligned}
$$

$\operatorname{ARDL}(4,0,4,6,5)$ with the Schwarz Criterion value (-2.341619) was chosen among 14406 models. According to the Breusch-Godfrey serial correlation test, there were no serial correlations up to 4 lags in the selected model.

The bounds test statistics 5.501472 is above the significance level of I(1) bound(5.06), so there is a cointegration relationship between the variables.The cointegration coefficient of the model is -0.231445 and is between 0 and -1 .

Long-term relationship coefficients between variables are shown in the table below: 
Table 2. Long Term Coefficients

\begin{tabular}{|c|c|c|c|}
\hline Variable & Coefficient & Std. Error & t \\
\hline Ingrmilpc & 1.579854 & 0.849751 & $1.859197^{*}$ \\
\hline Innatomilpc & 1.440226 & 1.228621 & 1.172229 \\
\hline ter & 0.198514 & 0.085023 & $2.334835^{* *}$ \\
\hline Ingdp & 0.476351 & 0.372536 & 1.278672 \\
\hline Constant & -20.126733 & 17.071266 & -1.178983 \\
\hline
\end{tabular}

Note: Significant at $*=\% 10, * *=\% 5, * * *=\% 1$ level

Results show that Turkey's military spending is in a long-term positive relationship with the military spending of Greece (at 10\% significance level) and domestic terror events (at 5\% significance level).

\section{Conclusion}

This study evaluates Turkey's military spending with economic and non-economic variables. ARDL bounds test results show that Turkey's military spending is in a long-term positive relationship with the military spending of Greece and domestic terror events. That is, an increase in the above variables results in an increase in Turkey's military spending in the long term.

\section{References}

Barnett, M. N. (1992), Confronting the Costs of War: Military Power, State and Society in Egypt and Israel,New Jersey: Princeton University Press.

Biddle, S. (2004). Military Power: Explaining Victory and Defeat in Modern Battle,Princeton, New Jersey: Princeton University Press.

Brzoska, M. (1995), "World Military Expenditires", Handbook of Defense Economics I, (Ed.) Keith Hartley and Todd Sandler), Amsterdam: ElsevierScience B.V., pp. 45-67.

Deger, S., \&Sen, S.,(1990). Military security and the economy: defence expenditure in India and Pakistan, The economics of defence spending: An international survey, (Ed.) K. Hartley and T. Sandler, London: Routledge, pp. 189-227.

Dehong, L. (2009). "The Role of the United States in theFuture Security Architecture for EastAsiafrom the Perspective ofChina-US Military-to-Military Interaction", The architecture of security in the Asia-Pacific, (Ed.) Huisken, R., Canberra, A.C.T: ANU E Press. pp. 85-100.

Fritz-ABmus, D., \& Zimmermann, K. (1990). West German demand for defence spending, The Economics Of Defence Spending: An international Survey, (Ed.) K. Hartley and T. Sandler, London: Routledge, pp. 118147.

Hartley, K. \& Sandler, T. (1990). The Economics of Defence Spending. An International Survey. London: Routledge. 
Kollias, C. \& Paleologou, S.M. (2003), Domestical political and external security determinants of the demand for Greek military expenditure, Defence and Peace Economics, 14(6), 437-446.

Looney, R. E. (1994), The Economics of Third World Defense Expenditures, London: Jai Press, Inc.

Looney, R.E., \&S.L. Mehay, (1990), United States defence expenditures: trends and analysis, The Economics Of Defence Spending: An international Survey, (Ed.) K. Hartley and T. Sandler,London: Routledge, pp. 13-40.

OECD. (2016).Trends Shaping Education 2016, Paris: OECD Publishing, Paris. http://dx.doi. org/10.1787/trends_edu2016-en

Richardson, L.F. (1960).Arms and insecurity: A mathematical study of causes and origins of war. Pittsburgh, PA: Boxwood Press.

Rosen, H. S., \& Gayer, T. (2008). Public Finance. Boston: McGraw-Hill Irwin.

Saunders, P. (1993), "Recent Trends in the Size and Growth of Government inOECD Countries", The Growth of the Public Sector, (Ed.) Norman Gemmell,England: Edward Elgar Publishing Limited, ss. 17-33.

Schmidt, C., L. Pilandon and J. Aben, 1990, Defence spending in France: the price of independence, The Economics Of Defence Spending: An International Survey, (Ed.) K. Hartley and T. Sandler, London: Routledge, pp. 93-117.

Sezgin,S., Yildirim, J., (2002). The demand for Turkish defence expenditure. Defence and Peace Economics 13, pp.121-128.

SIPRI. (1973). The Meaning and Measurement of Military Expenditure, SIPRI Research Report No:10, Agust 1973, https://www.sipri.org/publications/1973/meaning-and-measurementmilitary-expenditure (10.01.2019).

Smith, R. (1989).“Models of military expenditure”. Journal of Applied Econometrics, 4,pp. 345-359.

Sümer, K. K. (2005). "Investigation of the Effects of Defense Expenditures on Economic Growth". The Journal of Security Strategies, 1(1), ss. 82-91. 